\title{
Mulberry whitefly (Pealius mori) interference with silkworm (Bombyx mori) nymphal development
}

\author{
Shaaban Abd-Rabou ${ }^{1}$ - Alvin M. Simmons ${ }^{2}$. Usama M. Ghazy ${ }^{3}$
}

Accepted: 17 January 2019 / Published online: 19 March 2019

(C) The Author(s) 2019

\begin{abstract}
The mulberry whitefly (Pealius mori Takashashi) is increasingly causing concern in agriculture as the distribution of this pest expands. In Egypt, the recent invasion and population expansion of the mulberry whitefly has caused particular concern in the sericulture industry. The silkworm (Bombyx mori L.), also called mulberry silkworm or Chinese silkworm, is the most important source for natural silk production. A study was conducted to examine interference by the mulberry whitefly on the population development of the silkworm. White mulberry (Morus alba L.) leaves were obtained from trees maintained in the field which had different levels of natural infestation of whiteflies (P. mori), and these were fed to silkworms in the laboratory. Regardless of instar, all silkworm caterpillars that fed and developed on white mulberry leaves that were moderately whitefly-infested (350-450 nymphs per leaf) or heavily whitefly-infested (1650-1750 nymphs per leaf) failed to molt to the next instar or failed to pupate. By comparison, $88-95 \%$ of the caterpillars that were fed non-infested mulberry leaves molted and pupated. This study demonstrates that infestation of mulberry by P. mori can have a significant negative impact on the development of silkworms. These results have high economic implications for the sericulture industry.
\end{abstract}

Keywords Silkworm $\cdot$ Whitefly $\cdot$ Insect-interaction $\cdot$ Interference $\cdot$ Diet $\cdot$ Development $\cdot$ Sericulture $\cdot$ Bombyxmori $\cdot$ Pealiusmori

\section{Introduction}

Whiteflies are widely distributed around the world. The mulberry whitefly (Pealius mori Takahashi) is among the important agricultural whitefly pests. Abd-Rabou and Evans (2013) reported on the first detection of P. mori in Egypt where they found this invasive whitefly feeding on Euphorbia sp. in Giza during February in 2013. Thereafter, populations of this pest have continued to increase and spread in Egypt. This invader has since been reported in Greece where it was found feeding on white mulberry, Morus alba L. (Wang et al. 2016). It has

Alvin M. Simmons

alvin.simmons@ars.usda.gov

1 Agricultural Research Center, Scale Insects and Mealybugs Research Department, Whiteflies Unit, Plant Protection Research Institute, Dokki, Giza, Egypt

2 USDA, Agricultural Research Service, U.S. Vegetable Laboratory, 2700 Savannah Highway, Charleston, SC 29414, USA

3 Agricultural Research Center, Sericulture Research Department, Plant Protection Research Institute, Dokki, Giza, Egypt the potential to become a major pest of mulberry in the Mediterranean region. In addition to outbreaks in China where this whitefly was first reported (Takahashi 1932), P. mori experiences serious outbreaks on mulberry in India (David and Ragupathy 2004) and Thailand (Monchan et al. 2009). Known hosts of $P$. mori include members of the families Euphorbiaceae (Glochidion philippicum C.P. Robin), Moraceae (Ficus sp., Morus alba and M. australis Poiret), and Salicaceae (Salix sp.) (Evans 2007; Abd-Rabou and Evans 2013). Although another whitefly species (Tetraleurodes mori Quaintance) that occurs in the Americas shares the same common name and mulberry host with $P$. mori, the former has a much wider host range, is quite different taxonomically, and is not known in the Mediterranean region. These two species are among over 1500 described species of whiteflies in 161 genera around the world (Martin and Mound 2007).

The silkworm (Bombyx mori L.), also called mulberry silkworm or Chinese silkworm, is the most important arthropod species used in the global production of natural silk (Barber 1992). Mulberry leaves are essential in sericulture as food for the growth and development of B. mori. Nutrition is one of the basic requirements in sericulture, and insect quality, including 
Table 1 Survival of each larval instar of Bombyx mori when fed on different levels of whitefly (Pealius mori)-infested mulberry leaves

\begin{tabular}{llllllll}
\hline Variable & Experiment & Treatment & 1st instar & 2nd instar & 3rd instar & 4th instar & 5th instar \\
\hline $\begin{array}{l}\text { Mean } \pm \text { SEM \% of larvae developing } \\
\text { to next molt or pupation* }\end{array}$ & $\begin{array}{c}\text { Moderate whitefly } \\
\text { infestation }\end{array}$ & Infested & 0 & 0 & 0 & 0 & 0 \\
& Non-infested & $90.4 \pm 1.5$ & $92.8 \pm 2.2$ & $90.0 \pm 1.4$ & $94.8 \pm 1.4$ & $95.2 .6 \pm 0.8$ \\
& Heavy whitefly & Infested & 0 & 0 & 0 & 0 & 0 \\
& infestation & Non-infested & $87.6 \pm 2.9$ & $87.6 \pm 2.6$ & $90.4 \pm 2.1$ & $93.2 \pm 2.1$ & $93.6 \pm 1.7$ \\
Mean \pm SEM \% survival during 8 days & Moderate whitefly & Infested & $64.4 \pm 3.8$ & $67.6 \pm 3.4$ & $58.0 \pm 2.8$ & $80.8 \pm 2.1$ & $80.8 \pm 1.0$ \\
(1st-4th instars) or 10 days (5th instar)* & infestation & Non-infested & $90.4 \pm 1.5$ & $92.8 \pm 2.2$ & $90.0 \pm 1.4$ & $94.8 \pm 1.4$ & $95.2 \pm 0.8$ \\
& Heavy whitefly & Infested & $9.6 \pm 2.3$ & $6.0 \pm 1.9$ & $7.2 \pm 1.6$ & $35.6 \pm 3.0$ & $46.0 \pm 2.4$ \\
& infestation & Non-infested & $87.6 \pm 2.9$ & $87.6 \pm 2.6$ & $90.4 \pm 2.1$ & $93.2 \pm 2.1$ & $93.6 \pm 1.7$ \\
\hline
\end{tabular}

*All means within a column per instar per experiment are significantly different at $P<0.001$ according to t-test

cocoon weight, is among the most important traits for sericulture economics (Hemmatabadi et al. 2016). It is well-known that diet is an essential factor that can affect animal growth and development. Namely, a good diet may result in good biological performance while an inferior diet may result in an inferior performance. The total protein level in 5th instar larvae of $B$. mori has been demonstrated to be reduced with a moderate decrease in caloric consumption ( $\mathrm{Li}$ et al. 2009). When competing for the same resource, some arthropods may interfere with the populations of others (Grant and Grant 2006). The objective of this study was to determine any effect of mulberry whiteflyinfected mulberry leaves on the development of $B$. mori caterpillars compared with whitefly-free mulberry leaves.

\section{Materials and methods}

The source of plant materials for this study was M. alba leaves (variety Canava 2) collected from the experimental farm of the Plant Protection Research Institute in El-Qanater El-Khariys, in Qalyubiya Governorate in Egypt. All silkworms in this experiment were from a laboratory colony from the abovementioned research farm. Leaves from the mulberry plants were arranged into three categories: leaves with no whitefly-infestation, slightly whitefly-infested leaves (about 350-450 P. mori nymphs per lower leaf surface), and heavily whitefly-infested leaves (about 1650-1750 P. mori nymphs per lower leaf surface). All categories of leaves were collected from multiple mulberry trees and were a result of natural whitefly infestation. Detached fresh leaves were held in a laboratory cage at $26^{\circ} \mathrm{C}, 65-70 \%$ relative humidity, and a $16: 8 \mathrm{~h}$ light:dark photoperiod. Treatments consisted of whiteflyinfested leaves and the control consisted of non-infested leaves. The amount of leaves provided to $B$. mori varied based on the stage of the larval instar of the silkworm. Assays were set up consisting of 50 larvae of first, second, third, fourth and fifth instars that were provided 2, 3, 5, 16 and $45 \mathrm{~kg}$ of leaves, respectively. Paired trials of a control treatment and a treatment of heavily whitefly-infested leaves were set up. The leaves and silkworm larvae were confined in plastic cages ( $30 \mathrm{~cm}$ wide $\times 30 \mathrm{~cm}$ long $\times 20 \mathrm{~cm}$ high). There were five replicates for each of the five instars of $B$. mori. The experiment was repeated with paired trials of non-infested control leaves and moderately whitefly-infested leaves. The silkworm larvae on the leaves were observed daily for molting to the next instar or development to the pupal stage. First, second, third and fourth instar caterpillars were each observed for 8 days, while the fifth instar caterpillar was observed for

Table 2 Duration of each larval instar of Bombyx mori when fed on different levels of whitefly (Pealius mori)-infested mulberry leaves

\begin{tabular}{|c|c|c|c|c|c|c|c|}
\hline Variable & Experiment & Treatment & 1 st instar & 2nd instar & 3rd instar & 4th instar & 5th instar \\
\hline \multirow{4}{*}{$\begin{array}{l}\text { Mean } \pm \text { SEM duration (days) } \\
\text { to molt or pupation* }\end{array}$} & \multirow{2}{*}{$\begin{array}{l}\text { Moderate whitefly } \\
\text { infestation }\end{array}$} & Infested & 0 & 0 & 0 & 0 & 0 \\
\hline & & Non-infested & $4.5 \pm 0$ & $2.8 \pm 0.12$ & $4.8 \pm 0.12$ & $5.0 \pm 0$ & $8.9 \pm 0.29$ \\
\hline & \multirow{2}{*}{$\begin{array}{l}\text { Heavy whitefly } \\
\text { infestation }\end{array}$} & Infested & 0 & 0 & 0 & 0 & 0 \\
\hline & & Non-infested & $4.1 \pm 0.19$ & $2.8 \pm 0.12$ & $4.3 \pm 0.12$ & $4.7 \pm 0.12$ & $8.6 \pm 0.33$ \\
\hline \multirow{4}{*}{$\begin{array}{l}\text { Mean } \pm \text { SEM duration (days) } \\
\text { of feeding* }\end{array}$} & \multirow{2}{*}{$\begin{array}{l}\text { Moderate whitefly } \\
\text { infestation }\end{array}$} & Infested & $1.0 \pm 0$ & $1.0 \pm 0$ & $1.5 \pm 0$ & $2.2 \pm 0.26$ & $4.4 \pm 0.18$ \\
\hline & & Non-infested & $4.5 \pm 0.19$ & $2.8 \pm 0.27$ & $4.8 \pm 0.12$ & $5.0 \pm 0.2$ & $8.9 \pm 0.29$ \\
\hline & \multirow{2}{*}{$\begin{array}{l}\text { Heavy whitefly } \\
\text { infestation }\end{array}$} & Infested & $1 \pm 0$ & $1 \pm 0$ & $1 \pm 0$ & $1 \pm 0$ & $1 \pm 0$ \\
\hline & & Non-infested & $4.1 \pm 0.19$ & $2.8 \pm 0.12$ & $4.3 \pm 0.27$ & $4.7 \pm 0.27$ & $8.6 \pm 0.33$ \\
\hline
\end{tabular}

*Differences within a column between infested and non-infested are significantly different at $P<0.001$ according to t-test 
10 days. For each assay, fresh leaves were provided once to the silkworms. A total of 2500 larvae were set up in the experiment. The data were analyzed using procedures of SAS (SAS Institute 2012). Data for each whitefly-infested leaf treatment experiment were analyzed separately by instar and were subjected to the Student's $t$ test procedure. Percentages were transformed using arcsine transformation before the analysis. Actual means and standard errors are presented in the text.

\section{Results and discussion}

No molting or pupation occurred for larvae of any instar of $B$. mori reared on either moderately or heavily infested mulberry leaves (Table 1). By contrast, the percentages of the larvae developing to the next instar or to pupation were high (88-95\%) for those fed whitefly-free mulberry leaves (Table 1). Mortality was high for caterpillars fed whiteflyinfested leaves (Table 1). For each instar, there was no replication effect on survival among larvae in the non-infested treatment. The duration of time to molt or pupation was affected by the treatment (Table 2). Excess food was available for all caterpillars in each assay. For caterpillars on the noninfested check leaves, no more than about $50 \%$ of the leaves were consumed. By contrast, no more than about $25 \%$ of the whitefly-infested leaves were consumed. One obvious reason for less consumption on the whitefly-infested leaves is due to caterpillar mortality. Also, although no behavior data were collected, larvae that were provided heavily whiteflyinfested leaves appeared to be much less active in feeding, starting on the first day, as compared to larvae on the whitefly-free leaves. The effect of caloric restriction may be complex and not restricted to a single cause ( $\mathrm{Li}$ et al. 2009). Moreover, the duration of the larval stage can be extended with a depletion of juvenile hormone esterase (Zhang et al. 2017). Results from the current study have direct implications on silkworm rearing and silk production. Notably, moderate or high levels of populations of whiteflies on mulberry leaves can lead to a direct loss of silkworms.

There is a high likelihood that $P$. mori will continue to spread to more countries through transportation or other modes of dispersal. Specimens of $P$. mori have been intercepted at the Republic of Korea port of entry, but it has not been reported to have established in that country (Shu and Ji 2014). Many insecticide options may be available to manage whiteflies on mulberry, but it is essential that the chemical or chemical residues do not affect the silkworm which needs quality mulberry leaves. In a recent laboratory and field study with 12 isolates of entomopathogenic fungi, researchers demonstrated that Beauveria bassiana (Balsamo-Crivelli) can be effective in controlling P. mori on mulberry without leaving any residue that could harm silkworms that would later feed on the leaves (Maketon et al. 2009).
This study was not designed to identify specifically what aspects of leaf quality affected by $P$. mori rendered mulberry leaves unsuitable for silkworms. There may be one or a combination of factors. Not only does the whitefly interact with the plant by removing sap from the pholem, but excretions from P. mori results in mold buildup on the leaves. Moreover, it is not known if the whiteflies that were consumed by the silkworms had negatively affected the performance of the silkworms. Worldwide, at least 24 species of whiteflies attack mulberry (Wang et al. 2016). These data document that among these species, at least P. mori can interfere with and out-compete silkworms on mulberry. We suspect that other whitefly species that feed on mulberry may also negatively impact the population of silkworms.

Acknowledgements The authors thank Amnon Levi and Philip Wadl for helpful suggestions on the manuscript. This article reports the results of research only. Mention of a proprietary product does not constitute an endorsement or a recommendation for its use by USDA or the Egyptian Ministry of Agriculture.

Open Access This article is distributed under the terms of the Creative Commons Attribution 4.0 International License (http:// creativecommons.org/licenses/by/4.0/), which permits unrestricted use, distribution, and reproduction in any medium, provided you give appropriate credit to the original author(s) and the source, provide a link to the Creative Commons license, and indicate if changes were made.

Publisher's note Springer Nature remains neutral with regard to jurisdictional claims in published maps and institutional affiliations.

\section{References}

Abd-Rabou S, Evans GA (2013) Pealius mori - a new invasive whitefly to Egypt (Hemiptera: Aleyrodidae). Acta Phytopathologica et Entomologica Hungarica 48:333-334

Barber EJW (1992) Prehistoric textiles: the development of cloth in the neolithic and bronze ages with special reference to the aegean. Princeton University Press. p31

David V, Ragupathy E (2004) Whiteflies (Homoptera: Alyerodidae) of mulberry, Morus alba L., in India. Pestology XXVIII 10:24-33

Evans GA (2007) The whiteflies (Hemiptera: Aleyrodidae) of the world and their host plants and natural enemies. (Version 070606) http:// keys.lucidcentral.org/keys/v3/whitefly/PDF_PwP\%20ETC/worldwhitefly-catalog-Evans.pdf. Accessed 26 Aug 2017

Grant PR, Grant BR (2006) Evolution of character displacement in Darwin's finches. Science 313:224-226

Hemmatabadi RN, Seidavi A, Gharahveysis S (2016) A review on correlation, heritability and selection in silkworm breeding. J Appl Anim Res 44:9-23

Li Y, Chen K, Yao Q, Li J, Wang Y, Liu H, Zgang C, Huang G (2009) The effect of calorie restriction on growth and development in silkworm, Bombyx mori. Arch Insect Biochem Physiol 71:159-172

Maketon M, Orosz-Coghlan P, Hotaga D (2009) Laboratory and field evaluation of Beauveria bassiana for controlling mulberry whitefly 
Pealius mori Takahashi (Homoptera: Aleyrodidae) in mulberry (Morus alba Linn). J Pest Sci 82:251-259

Martin JH, Mound LA (2007) An annotated check list of the world's whiteflies (Insecta: Hemiptera: Aleyrodidae). Zootaxa 1492:1-84

Monchan M, Orosz-Coghlan P, Hotaga D (2009) Laboratory and field evaluation of Beauvaeria bassiana for controlling mulberry whitefly Pealius mori Takahashi (Homoptera: Aleyrodidae) in mulberry (Morus alba Linnn). J Pest Sci 82:251-259

SAS Institute (2012) SAS/STAT user's guide, version 9.4. SAS Institute, Cary, NC

Shu S-J, Ji J (2014) A checklist of whiteflies (Hemiptera: Aleyrodidae) intercepted on imported plants in Korea 2005-2013. Insecta Mundi 0354:1-14
Takahashi R (1932) Aleyrodidae of Formosa, part I. Department of agriculture, government research institute. Formosa 59: $1-57$

Wang J-R, Perdikis D, Chalkia C, Harizanis P, Kalaitzaki A, Tsagkarakis A, Xu Z-H, Du Y-Z (2016) The occurrence of Pealius mori (Takahashi), Pealius machili Takahashi and Paraleyrodes minei Iaccarino (Hemiptera: Aleyrodidae) infesting Morus alba L. in Greece. Annales de la Société Entomologique de France 52:281-288

Zhang Z, Liu X, Shiotsuki T, Wang Z, Xu X, Huang Y, Li M, Li K, Tan A (2017) Depletion of juvenile hormone esterase extends larval growth in Bombyx mori. Insect Biochem Mol Biol 81:72-79 